\title{
PRESERVATION OF BONE PROTEINS AND DNA IN AN ANCIENT FISH CALLED 'WANDA'
}

STATHOPLOS*, Linda, Smithsonian Institution, Mailstop MSC/CAL, 10th and Constitution Ave. NW, Washington, DC 20560, U. S. A.; TUROSS, Noreen, Smithsonian Institution, Mailstop MSC/CAL, 10th and Constitution Ave. NW, Washington, DC 20560, U. S. A.

Skeletal fish remains, including several vertebrae (Teleostei incertae $\underline{\text { sedis), }}$, were recovered from the core catcher section (subbottom depth, $10.5 \mathrm{~m}$ ) of a piston core taken in the Gulf of California $\left(28^{\circ} 00.34^{\prime} \mathrm{N}, 111^{\circ} 31.32^{\prime} \mathrm{W}\right.$; $460 \mathrm{~m}$ water depth). Bottom water temperatures in this area are typically less than $10^{\circ} \mathrm{C}$. Bone material retained original crystal morphology as well as a chemical composition consistent with hydroxyapatite. Insoluble collagen from one small bone fragment, extracted by decalcification in EDTA, was AMS radiocarbon dated at 28,070 \pm 310 years b.p. (TO\#2190).

Proteins from ancient fish bone fragments were partitioned by sequential extraction into two soluble fractions, non-mineral-associated and mineralassociated, and an insoluble fraction. The amino acid compositions of these extracts were compared to modern fish bone extracts. Soluble fossil fish bone extracts were enriched in collagen, consistent with peptide bond cleavage in this molecule and retention of degradation products by the mineral matrix, as observed previously in other ancient bones.

Three non-collagenous bone cell-produced proteins, osteocalcin, osteonectin, and bone sialoprotein, were identified immunochemically by ELISA (enzyme-linked immunosorbent assay) in the mineral-associated fraction from these ancient fish bones. The serum protein albumin was also identified immunochemically, suggesting that hydroxyapatite binding may enhance preservation of biomolecules in the fossil record. DNA, another molecule that binds to hydroxyapatite, was also observed in the mineral-associated ancient fish extract. The DNA showed signs of both in situ cleavage and complexing to an autofluorescent component that has been observed in other ancient specimens. Thus, the continuous presence of water does not by itself preclude preservation of non-collagenous proteins, insoluble collagen, or DNA in bone for tens of thousands of years. Anoxia and low temperatures afforded by burial in this basin slow molecular decay.

Small animals are underrepresented in the vertebrate terrestrial fossil record primarily due to differential preservation of skeletal material. Oceanic sediments provide an underexploited source of small vertebrate remains containing molecular as well as morphological information with chronometric and systematic utility. 